\title{
IMPROVING STUDENTS' ABILITY TO WRITE DESCRIPTIVE TEXT BY USING NUMBERED HEADS TOGETHER (NHT)
}

\author{
Abdul Rabbi Arrasul ${ }^{1}$, Muhammad Ibnu Umair ${ }^{2}$ \\ ${ }^{1}$ PBI FKIP UM Luwuk, ${ }^{2}$ PBI FKIP UM Luwuk \\ Email: arrasulabdulrabbi@gmail.co.id ${ }^{1}$, umairibnu12@gmail.com²
}

\begin{abstract}
Abstrak
Tujuan dari penelitian ini adalah untuk menentukan apakah menggunakan Numbered Heads Together (NHT) dapat meningkatkan kemampuan siswa untuk menulis teks deskriptif di SMPN 6 Toili Barat. Penelitian ini menggunakan penelitian eksperimental semu yang membutuhkan post-test untuk kedua kelompok. Populasi penelitian adalah siswa kelas delapan SMPN 6 Toili Barat. Sampel penelitian ini adalah kelas VIIIA sebagai kelas eksperimen yang terdiri dari 26 siswa dan kelas VIIIB sebagai kelas kontrol yang terdiri dari 27 siswa. Dalam mengumpulkan data, peneliti menggunakan tes. Tes terdiri dari pretest dan post-test. Data dianalisis secara statistik. Setelah dianalisis, hasil terhitung adalah 6,744, dengan derajat kebebasan 51, dan tingkat signifikansi 0,05, t-tabel adalah 1,675. Oleh karena itu, hasil t-hitung lebih tinggi dari t-tabel. Artinya, hipotesis dari penelitian ini dapat diterima. Hasil penelitian menunjukkan bahwa ada pengaruh yang signifikan dalam menggunakan Numbered Heads Together untuk meningkatkan kemampuan menulis siswa dalam teks deskriptif di kelas delapan SMPN 6 Toili Barat.
\end{abstract}

Kata kunci: Meningkatkan; Menulis; Dekriptive Teks, NHT.

\section{Abstract}

The purpose of this research is to determine whether using Numbered Heads Together (NHT) can improve students' ability to write descriptive texts at SMPN 6 Toili Barat. This research uses quasi-experimental research that requires a post-test for both groups. The research population was eighth grade students of SMP 6 Toili Barat. The sample of this research was class VIII A as an experimental class and consisted of 26 students while class VIII B was a control class and consisted of 27 students. The test consisted of pre-test and post-test. Data were analyzed statistically. After being analyzed, the result of $t$-counted was 6,744 with a degree of freedom 51, and a significance level of 0,05, $t$-table was 1,675. Therefore, the t-test result is higher than the t-table. It means that the hypothesis of this research can be accepted. The result showed that there was a significant influence in using Numbered Heads Together to improve students' writing abilities in descriptive text in eighth grade at SMPN 6 Toili Barat

Keywords: Improving; Writing; Descriptive Text; NHT. 


\section{Introduction}

Writing is an activity to convey, express feelings, and share experiences through written form. Writing can also be defined as a way to express feelings and ideas about a subject to communicate with others and also help to remember facts and details. There are four types of writing, namely expository, narrative, descriptive, and persuasive.

The researcher has done an observation in SMPN 6 Toili Barat and found problems related to English subjects, especially in writing ability. Students are not interested and it is not a pleasant thing for students in junior high school to write any types writing. Students find it difficult to express the contents of their thoughts in writing, and some students have ideas but cannot express them in their own sentences. They also lack of vocabulary related to the ideas they want to write. Based on the junior high school curriculum recommended by the government, there are several texts that must be mastered by junior high school students. One of them is descriptive text.

Descriptive text is a type of text that aims to explain or describe a person, animal, place or object. Generally, what is described is the shape, characteristics, or nature. In learning descriptive texts, students in SMPN 6 Toili Barat may experience difficulties in writing descriptive text. They are confused about what to write even though they knew the topic given by the teacher. They are confused about how to put their ideas into writing about the topic.

Therefore, the researcher used the Numbered Heads Together technique in teaching the students to write descriptive text. It is expected to help the students solve their problems that are mention above. Number Heads Together is a learning model that emphasizes the activities of students in finding, processing, and reporting information from various sources which are finally presented in front of the class. Numbered Heads Together (NHT) was first introduced by Kagan Spencer in 1993. The Numbered Heads Together model is part of a structural cooperative learning model, which emphasizes special structures designed to influence patterns of student interaction. The Kagan structure requires students to work interdependently on small groups cooperatively. Structures are developed as alternative materials from traditional class structures such as raising hands first to then be appointed by the teacher to answer the questions asked. This atmosphere will create a stir in the class, because students will be enthusiastic to fight for the opportunity to answer the researcher's questions. NHT learning model indirectly trains students to share information, listen carefully, talk calculatingly, and work together, so students are more productive in learning.

Based on the background above, the researcher took a title of this research is Improving Students' Ability to Write Descriptive Text by Using Numbered Heads Together (NHT)

\section{a. $\quad$ Nature of Writing}

Writing is the process of sharing information, messages, ideas, or thoughts that are poured into sentences with correct grammar. Writing is one of four language skills that are considered difficult skills and are also difficult lessons at school. This is because students must make text using English with correct grammar.

Harmer (2004) states that writing is a way to produce language and express ideas, feelings, and opinions. Harmer (2001) also mentions that writing involves planning what we are going to write. First, is drafting. Next is reviewing and editing what we have written and producing a final version. Writing as a form of problem solving in which the writer is faced with two main tasks: a) generating ideas, and b) composing these ideas into a written text that meets the needs of the readers and efficiently communicates the authors' messages (Hamp-Lyons, L., \& Heasly, 2006).

Furthermore, Peha (2010) states that writing is a communication of content for a 
purpose to an audience. Therefore, writing can be said as a process of giving and putting ideas or messages into words. So that when someone writes, the expressions that are produced should be meaningful and coherent. It aims to make the reader or the receiver get the message of their writings without any miscommunication.

\section{b. Aspect of Writing}

In order to write well, there are several aspects which should be considered by students. According to Jacob et al (1981) he proposes five aspects of writing, namely content, organization, vocabulary, language use, and mechanic. Content, content refers to substance of writing, the experience of the main idea (unity), i.e., groups of related statements that a writer presents as unit in developing a subject. Content paragraph do the work of conveying ideas rather than fulfilling special function of transition, restatement, and emphasis. Organization, it refers to the logical organization of the content (coherence). It is scarcely more than an attempt to piece together all collection of facts and jumble ideas. Even in early drafts it may still be searching for order, trying to make out patterns in its material and working to bring the particulars of his subject in line with what is still only a half-formed notion of purpose. Vocabulary, it refers to the selection of words those are suitable with the content. It begins with the assumption that the writer wants to express the ideas as clearly and directly as he can. As a general rule, clarity should be his prime objective. Choosing words that express his meaning is precisely rather than skew it or blur it. Language use, it refers to the use of the correct grammatical and syntactic pattern on separating, combining, and grouping ideas in words, phrases, clauses, and sentences to bring out logical relationships in paragraph writing. Mechanic, it refers to the use graphic conventional of the language, i.e., the steps of arranging letters, words sentences, paragraphs by using knowledge of structure and some others related to one another.

From Jacob's opinion it can be concluded that aspects of writing are content, organization, vocabulary, language use, and mechanics. By looking at the statement above, it can compose the perfect writing and can be understood by the reader. By looking at the statement above, it can be said that writing varies and there are several aspects in writing that must be considered in writing. In this research, researcher will only focus on three aspects of writing, namely content, use of language, and mechanics.

\section{c. Descriptive text}

According to Anderson and Anderson (2003), descriptive text describes particular person, place, or things. It means that descriptive text is designed specially about a person, a place, or things. They also stated descriptive text to tell about subject by describing its feature without including personal opinions.

Furthermore, Buscemi (1990) states that description is kind of writing used for presenting a verbal portrait of a person, or thing. This writing is used when the writers want to give details information and to make vivid writing. In other words, it used to develop a picture of "what is look like" it seems that the interpretation of the writer will color the result of the writing. It is because the writer does not only give the information itself, but also creates the certain image of the object.

Based on the opinions of the experts above, it can be concluded that descriptive text is text that give description about something. It can be person, animal, place or object physically.

\section{d. Numbered Heads Together (NHT)}

Numbered Head Together is one technique in cooperative learning. Cooperative learning is a teaching technique taught by teachers to students in groups that usually consist of four students to discuss topics together. That the purpose of cooperative 
learning is not only to make students active but also to train them to socialize, work together and help each other. Huda stated that "numbered heads together gives the students chance to share ideas and discuss the best answer. Then, numbered head together also can improve student motivation, and it can be used in all materials and all students level".

Numbered Heads Together (NHT) developed first by Kagan (1993) to involve more student in learning material which consist in a lesson and to know their knowledge about the material given. Numbered Heads Together technique is a group working which usually consists of four students, and each student has number 1 until 4, when teacher ask a question, they put their heads off together to discuss about the answer. Then teacher will call number randomly $(1,2,3$ or 4$)$ and students with that number can raise their hands to answer the question. Stone, H., \& Sidel (2004) states that, "Numbered Heads Together (NHT) is a simple four-step structure. Its main strengths are in building mastery and in reviewing previously learned information". Moreover, Slavin (1995) explain that, "Numbered Head Together (NHT) is basically a variant of group discussion; the twist is having only one student represent the group but not informing the group in advance who will be the representative".

e. Teaching Descriptive text using NHT

According to Lie (2002), there are some steps of Numbered Heads Together, they are:

1) Teacher divides the students into group of work of 4.

2) Teacher numbers the student from 1 to 4 in each group.

3) Teacher gives a problem.

4) In presenting the result of students work, the teacher calls the number of students from 1 to 4 randomly.

5) For each team, the student whose number was called answers the question. They may not receive any help from their team at this point. If they didn't pay attention during the discussion, it's too bad.

6) When all teams have shown their own work, the teacher checks each teams answer for accuracy.

7) The teacher can give the other question or problems if times allows.

Additionally, Ibrahim (2000) there are four steps of Numbered Heads Together, there are:

1) Numbering. Teacher divides the students into groups consisting of 4-6 persons and each member of the group would have number among 1-6.

2) Submitting Question. Teacher asks the question to the students. The question can be varied, specific or in interrogative form.

3) Collective Thinking. Students elaborate opinion toward the answer of the question, and make sure that every member in group knows the answer.

4) Answering. Teacher calls certain number, and then all of the students whose number has been called raise their hand. The teacher asks one of the students whose number has been called to present the result of his group. The next step is that the teacher requests another student but still has the same number but has different opinion to go in front of the class to present the result of his own group. The other students with the same number or different number get the same chance to ask question to his friend who does presentation in front of the class. If none of them asks, then teacher would ask the question for students in front of the class, and if no answer from the students then the question would be asked to the others student.

From several steps according to the several theories above, the teaching steps to 
write descriptive text using NHT technique are as follows:

1. Pre-teaching

In this activity, the activities carried out during the descriptive learning activity text with NHT technique include:

1) Greetings to start learning activities;

2) Condition students to be ready to take part in learning activities;

3) Ask class attendance;

4) Provide an explanation of the objectives of the learning activities to be carried out.

2. While-teaching

a. Exploration

b. In the investigation activities carried out between other:

1) The teacher asks students questions about the material to be studied;

2) The teacher explains the additional material of descriptive text;

3) The teacher explains how to make descriptive text;

4) The teacher explains the NHT method

c. In the elaboration activities of the activities carried out between other:

1) Teachers form students into several groups, each group 3-4 members, each student is given a different number for account for individual work;

2) Teachers give assignments to students to do with their groups;

3) Students work on the tasks that the teacher has given in groups;

4) Teachers call students randomly based on their numbering group, to write the results of their work.

d. Confirmation

In confirming activities, the students revised and edited their writing. The students discuss about their work with their group

3. Closing

In closing activities, the activities carried out include:

1) The teacher asks students about things that are not yet known;

2) Teachers and students together to correct misunderstandings, and teachers give revolution and conclusion;

3) Instruct students to explore the subject matter that has been given;

4) Inform students of learning activities at the next meeting;

5) Closing greetings.

\section{f. Hypothesis}

The alternative hypothesis of this research is, there is a significant effect in using Numbered Heads Together to improve the students' writing ability in descriptive text at eight grade of SMPN 6 Toili Barat.

Then null hypothesis, there is no significant effect in using Numbered Heads Together to improve the students' ability to write descriptive text at eight grade of SMPN 6 Toili Barat

\section{Research Method}

The researcher applied quasi-experimental design. The population of this research was eight grade students at SMPN 6 Toili Barat which consisted of two classes and to obtain the sample of this study, the researcher chose a control and experiment class based on the available classes of the eight grade students of SMPN 6 Toili Barat. The researcher selected for the research class VIII A as the experimental class, while class VIII B as the control class. 
There are two variables in this research, dependent variable was students' writing ability in writing descriptive text, while the independent variable was Numbered Heads Together (NHT). Then, the instrument of this research is a test. The test used was divided into two, pre-test and post-test.

This research described experimental procedures:

1. The pre-test was conducted to both of the class, experimental class, and control class, in order to know students' ability on writing descriptive text.

2. The researcher taught writing of descriptive text to both of experimental class and control class. In experimental class, the researcher applied Numbered Heads Together but not for control class.

3. Post-test was applied to know the students' ability in writing of the classes after the treatment is used in teaching. After that, the score of both classes were compared with the improvement.

Furthermore, the researcher analysed the data the individual score by using simple formula purposed by Sugiyono (2013):

$$
\sum=\frac{x}{n} \times 100
$$

After getting the individual score from the pre-test the data then were counted to find the mean score from each group. Mean or average is the sum of all the values in a distribution divided by the number of cases. The researcher computed the mean scores both in the experimental and control class by using a formula proposed by Sugiyono (2013):

$$
\begin{aligned}
& \overline{x_{1}}=\frac{\sum x_{1}---}{n_{1}} \\
& \overline{x_{2}}=\frac{\sum x_{2}---}{n_{2}}
\end{aligned}
$$

Then, the researcher computed the variance of each group. This average squared deviation or variance of each group was important to be calculated because it was used later in counting the t-test. If the standard deviation of a normal distribution was known, it was possible to compute the percentiles rank of the data. Sugiyono (2011, p. 276) proposed the formula in counting the variance for each sample group which can be looked at bellows:

$$
\mathcal{S}_{X}^{2}=\frac{n \cdot \sum X^{2}-\left(\sum X\right)^{2}---}{n(n-1)}
$$

The last, the researcher computed t-test in order to analyze the significance difference between the experimental group and the control group. The analysis of independent data sample the t-test was used to measure whether there was a positive influence in students' learning outcomes in experimental group after giving treatment or not.

$$
\mathrm{t}=\frac{\overline{x_{1}}-\overline{x_{2}}}{\sqrt{\frac{\left(n_{1}-1\right) \mathcal{S}_{1}^{2}+\left(n_{2}-1\right) \mathcal{S}_{2}^{2}}{n_{1}+n_{2}-2}\left(\frac{1}{n_{1}}+\frac{1}{n_{2}}\right)}}
$$




\section{Finding and Discussion Data Interpretation}

The researcher calculated every score gained by the students in both pre-test and post-test. In the following table, the mean score of pre-test and post-test data from both classes are listed with the summary of mean deviation and variance. Here is the interpretation of the table:

Table 1. Data Interpretation

\begin{tabular}{c|c|c|c|c|c|c|c|c}
\hline Sample & $\mathrm{N}$ & $\begin{array}{c}\text { Mean } \\
\text { Score of } \\
\text { Pre-test }\end{array}$ & $\begin{array}{c}\text { Mean } \\
\text { Score } \\
\text { of } \\
\text { Post- } \\
\text { test }\end{array}$ & $\begin{array}{c}\text { Mean } \\
\text { Deviatio } \\
\mathrm{n}\end{array}$ & $\begin{array}{c}\text { Varianc } \\
\mathrm{e}\end{array}$ & $\mathrm{df}$ & $\begin{array}{c}\text { Sig. } \\
\text { Level }\end{array}$ & $\mathrm{T}$ \\
\hline $\begin{array}{c}\text { Experime } \\
\text { ntal } \\
\begin{array}{c}\text { Control } \\
\text { Equal }\end{array}\end{array}$ & 26 & 46.46 & 73.57 & 26.80 & 149.06 & & & \\
$\begin{array}{c}\text { Variances } \\
\text { Assume }\end{array}$ & & 38.70 & 50.22 & 12.25 & 170.16 & & & \\
\hline
\end{tabular}

The above table represents the summary of statistic data. The mean score of pre-test from both classes are quite similar. After the treatment is conducted in experimental class, the mean score of the pre- test is highly improved. It can be seen in the mean deviation score of experimental class which is 26.80 . to test the hypothesis and to make sure the significance different from the data obtained, the analysis used was independent sample t-test with degree of freedom 51 0r equal to 1.675 in probability 0.05 . the result of data computation $\mathrm{t}$-counted is 6.744 . it was greater than $\mathrm{t}$-table $(\mathrm{df}=51,1.675)$. the result indicates that there is there is a significant effect in using Numbered Heads Together to improve the students' writing ability in descriptive text at eight grade of SMPN 6 Toili Barat. Therefore, the alternative hypothesis (Ha) in this research is accepted, while the null hypothesis (Ho) is rejected.

Based on the finding of the research, it is found that the students who were taught using Numbered Heads Together have improved their descriptive text writing ability. The result of this research also requires the comparison between the experimental class and the control class. It is found that the experimental and control classes' prior knowledge are almost similar in the pre-test. It is found that the experimental and control classes' prior knowledge are almost similar in the pre-test. It corresponds to the result of the both classes, the experimental class mean score in pre-test is 46.46 while the control class is 38.70 . It means, there is no significant difference between the two classes before conducting the treatment.

After giving the pre-test, it was time to apply treatment. In the first treatment applying (NHT) the researcher divided the students into several groups, each group consisted of 5-6 members, and each student was given a different number in each group, after which the researcher showed an example of descriptive text. Then the researcher gave the assignment of making a descriptive text and worked with each group. After finishing the assignment to make descriptive text, the researcher called students numbered head 1, students numbered head 1 in each group came forward to read descriptive text from the results of their discussion. The next assignment is read by students numbered heads $2,3,4$, and so on.

This strategy worked as the expectation of the researcher. Through this Numbered Heads Together the students became confident and more quite when joining a test. It is proven by the range score that the experimental class obtained. From 46.46 in the pre- 
test to 73.57 in the post-test, It indicates that NHT can improve students' ability to write descriptive text. NHT also made students interested in learning descriptive text. The students were easier to construct descriptive text from their ideas, and sharing each other by their group.

Both classes' achievements were not significantly different in pre-test, but after applying the treatment it was found that there are significantly different achievements between the students who are taught by applying NHT than those who are taught by no special treatment. It is based on the result of post-test of the experimental class compared to the control class in which the t-counted is 6.744 while the t-table (tt) for degree of freedom 51 and the level of significance $=0.05$ was 1.675 . So, the $t$-counted is greater than the t-table. It means that $\mathrm{Ho}$ is rejected and $\mathrm{Ha}$ is accepted. The result indicates that there is a significant effect in using NHT to improve the students' writing ability in descriptive text at eight grade of SMPN 6 Toili Barat. Briefly NHT is effective to increase or improved students' ability to write descriptive text.

\section{Conclusion}

Based on the discussion, the researcher concludes the research result. The conclusion can be drawn as follow: there is a significant effect in using Numbered Heads Together to improve the students' ability to write descriptive text. Because from the result of the data in previous chapter where null hypothesis (Ho) is rejected and alternative hypothesis (Ha) is accepted. It means that the researcher concluded that there is a significant effect in using Numbered Heads Together to improve the students' ability to write descriptive text at the eight grade of SMPN 6 Toili Barat.

It was supported by the score achieved by the students in which they got higher scores after the researcher gave the treatment by using Numbered Heads Together. The result of the computation showed that the $\mathrm{t}$-count is 6.774 while the t-table is 1.675 , it means (Ho) is rejected and (Ha) is accepted. It can be proved from the testing hypothesis, where alternative hypothesis is accepted and null hypothesis is rejected.

In this part, the researcher proposes some suggestions as follow: 1) This method is suitable for teacher to use for students at the eight grade students in SMPN 6 Toili Barat to improve students' ability to write descriptive text. 2) The English teacher must create an interesting and pleasant atmosphere in the learning process, to prevent the students from being bored in order to focus and be comfortable in learning activities. 3) Students should improve more their knowledge in English. 4) The students should study hard and also practice more in writing to improve their ability of writing. 5) The students should pay attention to the teacher when he or she gives material or explanation. 6) This study used Numbered Heads Together to improve students' writing ability. It is expected for the next researcher that the result of this research can be used as additional references for further research conducted in the future to create a better teaching and learning process that Numbered Heads Together can be applied to improve students writing ability. Besides, the researcher knows that there are still some weaknesses in applying it. The researcher hopes some suggestions from other researcher to improve and make it better.

\section{References}

Anderson, M. and A. (2003). Text Types in English 1-2. Australia: Macmillan Education.

Buscemi, S. V. (1990). A Reader for Developing Writers. New York: McGraw-Hill Companies, Inc.

Hamp-Lyons, L., \& Heasly, B. (2006). Study Writing: A course in Writing Skills for Academic Purposes. 2nd ed, 6th print. Cambridge: Cambridge University Press.

Harmer, J. (2001). The Practice of English Language Teaching, 3rd Ed. New York: 
BEEJ, e-ISSN 0000-0000, Vol. 1, No. 1, March 2020

Pearson Education Limited.

Harmer, J. (2004). How to Teach Writing: Effective Sentence, Paragraph, and Essay. New York: Longman.

Ibrahim, dkk. (2002). Pembelajaran Kooperatif. Surabaya: Unesa University Press.

Jacobs, H. L., et.al. (1981). Testing ESL Composition: A Practical Approach. Rowley, MA: Newbury House.

Kagan, S. (1993). Cooperative Learning. San Juan Capistrano: Kagan Cooperative Learning.

Lie, A. (2002). Cooperative Learning in the Class Room. Jakarta: Gramedia Widiasarana.

Peha, S. (2010). The writing Teacher's Strategy guide. Retrieved May 19, 2019, from http://www.ttms.org.

Slavin, R. E. (1995). Cooperative Learning (Theory, Research, and Practice). Boston: Allyn and Bacon.

Stone, H., \& Sidel, J. L. (2004). Sensory Evaluation Practices third edition. Redwood City, California, USA: Elsevier Academic Press.

Sugiyono. (2011). Metode Penelitian Kuantitatif Kualitatif dan RD. Bandung: Alfabeta. Sugiyono. (2013). Metode Penelitian Kuantitatif Kualitatif dan RD. Bandung: Alfabeta. 